\title{
RECENT GEODYNAMICS AND SEISMICITY OF THE FAR EAST AND THE EASTERN SIBERIA
}

\author{
V. G. Bykov, A. N. Didenko, T. V. Merkulova \\ Yu.A. Kosygin Institute of tectonics and geophysics, Far Eastern branch of RAS, \\ 680000, Khabarovsk, Kim Yu Chen street, 65, Russia
}

\begin{abstract}
The information on the «Problems of seismicity and recent geodynamics of the Far East and Eastern Siberia» Symposium is presented. It was held on June 1-4, 2010 at the Yu.A. Kosygin Institute of tectonics and teophysics, Far Eastern branch, Russian academy of sciences, Khabarovsk. The scope of plenary meetings, sessions and round-table discussions conducted during the Symposium is presented with a brief review of the most interesting scientific reports.

Keywords: seismology, recent geodynamics, seismotectonics, deformation processes, focal zones, physics of the seismic process.
\end{abstract}

Recommended by S.I. Sherman 30 July 2010

Bykov V.G., Didenko A.N., Merkulova T.V. Recent geodynamics and seismicity of the Far East and the Eastern Siberia // Geodynamics \& Tectonophysics. 2010. V. 1. № 3. P. 313-321.

\section{СОВРЕМЕННАЯ ГЕОДИНАМИКА И СЕЙСМИЧНОСТЬ ДАЛЬНЕГО ВОСТОКА И ВОСТОЧНОЙ СИБИРИ}

\author{
В. Г. Быков, А. Н. Диденко, Т. В. Меркулова \\ Институт тектоники и геофизики им. Ю.А. Косыгина ДВО РАН, \\ 680000, Хабаровск, ул. Ким Ю Чена, 65, Россия
}

Аннотация: Представлена информация о симпозиуме «Проблемы сейсмичности и современной геодинамики Дальнего Востока и Восточной Сибири», проведенном 1-4 июня 2010 г. в Институте тектоники и геофизики им. Ю.А. Косыгина ДВО РАН (г. Хабаровск). Освещена тематика пленарных и секционных заседаний симпозиума, «круглых столов», дано краткое содержание отдельных наиболее интересных докладов.

Ключевые слова: сейсмология, современная геодинамика, сейсмотектоника, деформационные процессы, очаговые зоны, физика сейсмического процесса. 
The geodynamic regime and high seismicity of the Far East and the Eastern Siberia are mainly determined by interaction of the continental Eurasian, the North American and the Amur plates, at the one side, and the oceanic Pacific and Okhotsk plates, at the other side. The Baikal, Songliao- Amur-Zeya, AmurHanka, Japan and Okhotsk rifting systems have considerably influenced and continue to significantly impact the paleo- and recent geodynamics of the region.

Principally, the interference of these two geodynamic regimes is determinative of the stress-strain state of the lithosphere, activity and density of faults, seismicity, kinematics of horizontal and vertical displacements of the lithospheric plates and major blocks in the region under study. According to the recent geological and geophysical data, the major lithospheric plate boundaries are assumed as areas with complicated structures, that separate the plates from each other; they are composed of blocks bordered by seismically active faults. Tectonic stresses caused by plate interactions are transferred within these zones. On the most important problems in geodynamics is definition of mechanism providing for accumulation, propagation and redistribution mechanism of slow deformation processes' energy and transfer and release of tectonic stresses at the boundaries between blocks and lithospheric plates.

In addition to tectonic evidence, geodetic data on recent movements along faults are considered indicative of fault activity. Relatively rapid displacements of the active fault boundaries result in seismic activity.

Results of joint analyses of data on seismicity, active faults and horizontal displacement vectors (according to GPS measurements) provide major criteria for assessment of the recent geodynamics of the lithosphere and the basis for socially-focused studies related to forecasting of natural hazards and natural catastrophic phenomena.

Application of the state-of-the-art observation techniques, such as satellite geodesy, broad-band seismology, satellite radar topography mission (SRTM), and modern methods of data processing offers new possibilities for developing an integrated concept of the recent geodynamic activity in the Far East and the Eastern Siberia.

The «Problems of Seismicity and Recent Geodynamics of the Far East and the Eastern Siberia» Symposium, held on June 1-4, 2010 at the Yu.A. Kosygin Institute of Tectonics and Geophysics, Khabarovsk, covered the key geological and geophysical problems, including those related to recent geodynamics, seismicity, seismic zoning and seismic hazard assessment of areas, seismotectonics and earthquake source physics. It was the seventh in the regional seismological research tradition of such symposia (Khabarovsk, 1997, 2001; Petropavlovsk-Kamchatsky, 1999, 2004; Yuzhno-Sakhalinsk, 2002, 2007).

Special attention was traditionally focused on seismicity as the most striking manifestation of recent geodynamics. The Far East of Russia is one of the most seismically active region of the Earth, and numerous large seismic events have occurred in the recent decade. For this reason, the problem of seismicity and re- cent geodynamics of the Far East is of prime importance both for the fundamental research and assessment of the habitability of the region.

The main objective of the Symposium was to review studies of dynamics of deformation and seismic processes, geophysical monitoring, regularities of crustal deformations and their seismic manifestations in different regions of the Far East and the Eastern Siberia, as well as studies of seismogenic and focal zones and application of GIS technologies for natural hazard prediction.

The symposium participants came from the following cities of Russia:

- Moscow: Institute of Physics of the Earth, Russian Academy of Sciences (RAS), Geological Institute RAS, Institute of Oil and Gas Problems RAS, International Institute of Earthquake Prediction Theory and Mathematical Geophysics RAS, Mechanical Engineering Institute RAS,

- St. Petersburg: Physical-Technical Institute RAS,

- Obninsk: Geophysical Survey RAS,

- Krasnoyarsk: Ecological Center of PORP (Rational Use of Natural Resources),

- Irkutsk: Institute of the Earth's Crust, Siberian Branch (SB) of RAS,

- Novosibirsk: Institute of Oil and Gas Geology and Geophysics, SB RAS,

-Yakutsk: Institute of Geology of Diamonds and Precious Metals, SB RAS;

- Blagoveshchensk: Institute of Geology and Nature Management, FEB RAS;

- Birobidzhan: Institute for Complex Analysis of Regional Problems, FEB RAS;

- Khabarovsk: Institute of Tectonics and Geophysics, FEB RAS; Mining Institute, FEB RAS; Computing Center, FEB RAS;

- Vladivostok: Far East Geological Institute, FEB RAS; Institute of Applied Mathematics, FEB RAS; Pacific Oceanology Institute, FEB RAS; Pacific Geographical Institute, FEB RAS;

- Yuzhno-Sakhalinsk: Institute of Marine Geology and Geophysics, FEB RAS; Sakhalin Branch of the Geophysical Survey (GS), RAS;

- Petropavlovsk-Kamchatsky: Institute of Volcanology and Seismology, FEB RAS; Kamchatka Branch of GS RAS;

- Magadan: North Eastern Comprehensive Scientific and Research Institute, FEB RAS.

Among the symposium participants were Japanese researchers from the city of Sapporo who represented the Hokkaido University.

During the symposium, 19 reports were presented during two plenary meetings, and 52 presentations were delivered at five sessions as follows:

- Recent dynamics of the lithosphere and models of geological structures at different depth levels;

- Deformation processes within the crust and upper mantle;

- Seismicity of areas, seismic zoning, and quantitative estimations of seismic hazard;

- Seismic process, earthquake source physics, earthquake precursors and prediction;

- Seismotectonics, seismogenic and focal zones. 
Three round-table discussions covered the following topics:

- Targeted Comprehensive Research Program of the Far East Branch of the Russian Academy of Sciences «Recent Geodynamics, Active Geological Structures and Natural Hazards at the Far East of Russia» (2009-2013);

- Strain waves in the Earth: Application to seismicity and recent geodynamics;

- Detailed data on seismicity and seismic hazard inside the Russian Federation territory; development of next-generation mapping for general seismic zoning (OSR-2012).

The reports presented at the plenary meetings covered practically all the major problems of recent geodynamics and seismology. The first plenary paper titled "Tectonophysical model of the continental seismic zone: Development experience and problem objectives" was presented by S.I. Sherman (Institute of the Earth's Crust, SB RAS, Irkutsk) who set the high standard for the Symposium and sounded the key tone for constructive debate. Based on the well-studied fault tectonics and seismicity of the Baikal rift zone (BRZ), a tectonophysical model of BRZ was proposed. The scientific and practical value of this report is high due to the fact that the tectonophysical model with application of modern GIS-technologies provides for calculating probability of occurrence of individual earthquake foci and thus facilities mid-term forecasting of seismic events.

Among the topical scientific problem are studies of strain waves in fault zones which can initiate earthquakes. Two plenary reports presented by Yu.O. Kuzmin (Institute of Physics of the Earth RAS, Moscow) and V.G. Bykov (Institute of Tectonics and Geophysics, FEB RAS, Khabarovsk) were devoted to this subject. Yu.O. Kuzmin presented empirical research results on space-time migration of recent deformations in the fault zones in view of the current concepts of auto-wave processes. V.G. Bykov proposed the model of accumulation and propagation of energy of slow deformation processes and transfer and release of stresses at the lithospheric plate boundaries in transform fault zones.

In the report presented by G.I. Dolgikh (Pacific Oceanology Institute, FEB RAS, Vladivostok), technical characteristics of hard- and software appliances, which are based on broadband seismographs, GPS-receivers, strain meters and hydrophones, were analyzed in order to consider potential application of such equipment sets for studying variations of the stress-strain field of the Earth that result in natural hazards. Special attention was focused on the possibility of developing equipment on the basis of modern laser interference techniques for direct high-precision measurements of various parameters of the atmosphere, hydrosphere and lithosphere in a range of time and space scales.

In the report by $\mathrm{H}$. Takahashi (Hokkaido University, Sapporo, Japan), a review of geodetic and seismological data provided evidence that large earthquakes which occur at the Sakhalin Island and along the islands of Japan are associated with accumulation and release of stresses at the boundary between the Amur and Pacific plates and with displacement of the Amur plate towards Japan.

The technique and principles of general seismic zoning mapping of the Russian Federation territory (OSR-2012) were described in reports presented by V.I. Ulomov (Institute of Physics of the Earth, RAS, Moscow) and S.A. Peretokin (Ecological Center of PORP, Krasnoyarsk).

The study of linear structures which are important for resolving problems of recent geodynamics and seismology was presented in the report by A.N. Didenko and co-authors (Institute of Tectonics and Geophysics FEB RAS, Khabarovsk). Based on GIS-Technologies, they provided a comprehensive analysis of potential geophysical fields and a digital model of the relief and seismicity of the junction zone of the Central Asian folded belt and the Siberian Craton.

Regularities of the structure formation and kinematic types of conjugation of active faults in zones of dynamic influence of regional tectonic sutures comprising fault-block structures at the north-eastern flank of the Baikal rift, that accumulate significant tectonic stresses, were considered in the report presented by V.S.Imaev and co-authors (Institute of the Earth's Crust, SB RAS, Irkutsk).

In the presentation by N.I. Seliverstov (Institute of Volcanology and Seismology, FEB RAS, Petropavlovsk-Kamchatsky), possible nature of seismoactive zones underneath active volcanoes was considered in a hydro-convectional model of island-arc magmatism (as exemplified by the Klyuchevskoy Volcano). It was suggested that deep long-period earthquakes and volcanic tremor, as significant manifestation of seismicity of active volcanoes, may be related to processes of magma dehydration in magmatic canals and to closed magmatic circulation underneath island-arc volcanoes.

During the second plenary meeting held on the final day of the Symposium, the following reports were presented: A.V. Lander and co-authors (International Institute of Earthquake Prediction Theory and Mathematical Geophysics RAS, Moscow, and the Kamchatka Branch of GS RAS, Petropavlovsk-on-Kamchatka) reviewed scientific research results on seismic zones of Kamchatka; I.N. Tikhonov (Institute of Marine Geology and Geophysics FEB RAS, Yuzhno-Sakhalinsk) reported on studies of seismic quiescence periods as mid-term precursors for the large Kurils-Kamchatka earthquakes; and V.N. Chebrov and co-authors (Kamchatka Branch of GS RAS, Petropavlovsk-Kamchatsky) reported on application of GIS-technologies to tsunami disaster mitigation surveys in the Far East.

In his report "Seismotectonics and the earth tides", B.W. Levin (Institute of Marine Geology and Geophysics FEB RAS, Yuzhno-Sakhalinsk) reviewed preliminary research results on dependence of seismic activity of the Pacific lithosphere elements on their latitudinal positions. He presented a method to study seismic activity that envisages normalization of numbers of seismic events by lengths of the lithospheric plate boundaries for each latitudinal belt, and analysed the earthquake energy distribution in the latitudinal belts by depth.

Paleoseismodislocations in the Sakhalin fault zones were considered in the report by A.I. Kozhurin and co- 
authors (Geological Institute RAS, Moscow); their analysis provides for estimating earthquake magnitudes and recurrence intervals and thus contributes to development of long-term prediction of seismicity.

During the session on recent geodynamics of the lithosphere and models of geological structures at different depth levels, nine reports were presented. V.Yu. Timofeev and co-authors (Institute of Oil and Gas Geology and Geophysics, SB RAS, Novosibirsk) and S.V.Ashurkov and co-authors (Institute of the Earth's Crust, SB RAS, Irkutsk) focused on plate kinematics and determination of the Amur plate boundaries. The first report presented measurement results that provided for definition of the pole of the plate rotation relative to Eurasia. In the second report, positions of the northern and eastern boundaries of the Amur plate were specified.

Dynamics of the lithosphere at different depth levels in dislocation typical of the Kurils-Okhotsk and Sakhalin regions was analyzed in two reports presented by T.K. Zlobin and A.Yu. Polets (Institute of Marine Geology and Geophysics, FEB RAS, Yuzhno-Sakhalinsk). Their research results contribute significantly to determination of rheological properties of the crust and mantle of the regions under study.

During the session on seismicity of areas, seismic zoning and quantitative estimates of seismic hazard, reports on seismicity of the Far East area were presented. Based on data from the Primorye and Priamurye Earthquake Catalogue from 1865 to 2009, T.V. Nagornykh and N.S. Kovalenko (Institute of Marine Geology and Geophysics, FEB RAS, Sakhalin Branch of GS RAS, Yuzhno-Sakhalinsk) concluded that earthquakes of $M=4.4$ in the Primorsky Krai territory may provoke shakes at the epicentre with intensity levels up to 7 points (as per the MSK seismic intensity scale). More detailed studies of seismic hazard in the South Primorye become particularly important in view of intensive civil construction at the Russky Island (i.e. facilities for APEC-2012 Summit to be held in Vladivostok) and in the South Primorye territory. M.Yu. Andreeva (Institute of Marine Geology and Geophysics, FEB RAS, Yuzhno-Sakhalinsk) presented research results on the Kurils-Kamchatka seismically active area.

New achievements in developing methods for assessment of levels of seismicity and seismic hazard were described by V.A. Saltykov (Kamchatka Branch of GS RAS, Petropavlovsk-Kamchatsky) and M.Yu. Andreeva (Institute of Marine Geology and Geophysics, FEB RAS, Yuzhno-Sakhalinsk).

In the report by O.V. Lunina and A.S.Gladkov (Institute of the Earth's Crust, SB RAS, Irkutsk), which aroused much interest, a new approach to classification of active faults was proposed on the basis of modern concepts developed by researchers from Russia, Italy, the USA and Japan. In future, this research can bring seismic hazard assessments to a new level.

After the Sakhalin earthquakes of 25 May 1995 (Neftegorsk) and 02 August 2007 (Nevelsk) with disastrous damage and numerous victims, it became evident that more detailed seismic zoning of settlements at Sakhalin was required. These studies were reported by Kim Chun Un and co-authors (Institute of Marine Geol- ogy and Geophysics, FEB RAS, Yuzhno-Sakhalinsk, Institute of Oceanology RAS, Moscow) and A.V. Konovalov and co-authors (Institute of Marine Geology and Geophysics, FEB RAS, Yuzhno-Sakhalinsk).

The session on deformation processes in the crust and upper mantle was mainly focused on manifestation of strain wave processes which produce significant impact on geodynamics of seismic regions, especially those neighboring active segments of the Pacific seismic belt. The report by V.A. Bormotov (Institute of Tectonic and Geophysics, FEB RAS, Khabarovsk) presented research results on strain wave processes in the Priamurye territory that provide for prediction of periods of seismic activation in the area under study.

S.I. Sherman and E.A. Gorbunova (Institute of the Earth's Crust, SB RAS, Irkutsk) analysed slow strain wave processes in the lithosphere of the Baikal rift zone and presented convincing argumentation for their conclusion that the recorded trend of rupture growth and time sequence of earthquake foci occurrence at such ruptures suggest that these phenomena can be triggered by strain waves.

In East Asia, both weak and strong earthquakes can be caused by strain waves. A.A. Stepashko (Institute of Tectonics and Geophysics, FEB RAS, Khabarovsk) reported on the origin of seismic cycles during which strong earthquakes are observed.

A.I. Nikonov and co-authors (Institute of Physics of the Earth RAS, Moscow) reported on application of geodynamic process research results to address challenges of construction of the pipeline system for transportation of oil and gas from the Piltun-Astokhskoe and Lunskoe fields to the liquefied natural gas plant located near the city of Yuzho-Sakhalinsk and from marine platforms on the eastern shelf of the Sakhalin Island.

Most of the reports presented at the session on seismic process, earthquake source physics, precursors and earthquake prediction were devoted to prediction of seismicity intensification. Seismic emission anomalies, which occurred, in the authors' opinion, due to development of subsurface dilatancy zones prior to the occurrence of the Kamchatka earthquakes, was considered by V.A. Saltykov and Yu.A. Kugaenko (Kamchatka Branch of GS RAS, Petropavlovsk-Kamchatsky). The mechanism of the precursor of hydrogeodynamic type, that occurred before the Kronotsky earthquake (05 December 1997) was described by G.N. Kopylova and S.V. Boldina (Kamchatka Branch of GS RAS, Petropavlovsk-Kamchatsky).

Much interest was aroused by the reports presented by M.N. Luneva (Institute of Tectonics and Geophysics, FEB RAS, Khabarovsk), who reviewed new data on seismic anisotropy of the South Kurils arc, and A.V. Vikulin and co-authors (Institute of Volcanology and Seismology, FEB RAS, Petropavlovsk-Kamchatsky), who studied the relationship between seismic and volcanic processes at the Pacific margin.

Development and upgrading of the network of seismic stations, data acquisition systems and techniques for definition of earthquake parameters play a key role in seismic activity research. Prospects for the regional seismic network development in the southern Far East were highlighted in the report by Yu.N. Levin and co- 
authors (Sakhalin Branch of GS RAS, Yuzhno-Sakhalinsk). Issues of establishment of the seismic data acquisition, storage and transfer system at the Far East Branch were reviewed by A.A. Sorokin (Computing Center FEB RAS, Khabarovsk) and A.V. Konovalov (Institute of Marine Geology and Geophysics, FEB RAS, Yuzhno-Sakhalinsk).

During the session on seismotectonics, seismogenic and focal zones, the relationship between seismicity and modern tectonics was discussed. The key indicators of tectonic activity are active faults and fault zones. Problems of fault detection and fault activity assessment were considered in a number of reports, including those by A.A. Gavrilov (Pacific Oceanological Institute, FEB RAS, Vladivostok), M.N. Kondratiev (North Eastern Comprehensive Scientific and Research Institute, FEB RAS, Magadan) and A.M. Zhirnov (Institute for Complex Analysis of the Regional Problems, FEB RAS, Birobidzhan). A.T. Sorokina and co-authors (Institute of Geology and Nature Management, FEB RAS, Blagoveshchensk) and A.A. Kokovkin (Institute of Tectonics and Geophysics, FEB RAS, Khabarovsk) considered a relationship of radon and helium anomalies with active fault tectonics and seismicity.

Results of the georadar application to studies of seismotectonic deformations at Kamchatka were re- ported by T.K. Pinegina (Institute of Volcanology and Seismology, FEB RAS, Petropavlovsk-Kamchatsky) and by A.I. Kozhurin (Geological Institute RAS, Moscow).

The scope of scientific problems discussed at the Symposium reflects the current state-of-the-art of the world science in terms of natural hazard prediction. The presented research results on geodynamics, deformation, strain and seismicity contribute to the development of the informational basis which can provide for more clear definitions and assessment of seismic hazard at the Far East and Eastern Siberia.

It should be noted that a considerable number of reports presented at the Symposium resulted from the Targeted Comprehensive Research Program of the Far Eastern Branch of the Russian Academy of Sciences, titled «Recent Geodynamics, Active Geological Structures and Natural Hazards of the Far East of Russia» (2009-2013).

\section{ACKNOWLEDGEMENTS}

The Symposium was supported by the Russian Foundation for Basic Research (Grant 10-05-06023-G) and the Presidium of the FEB RAS (Grant 10-III-G-08025).

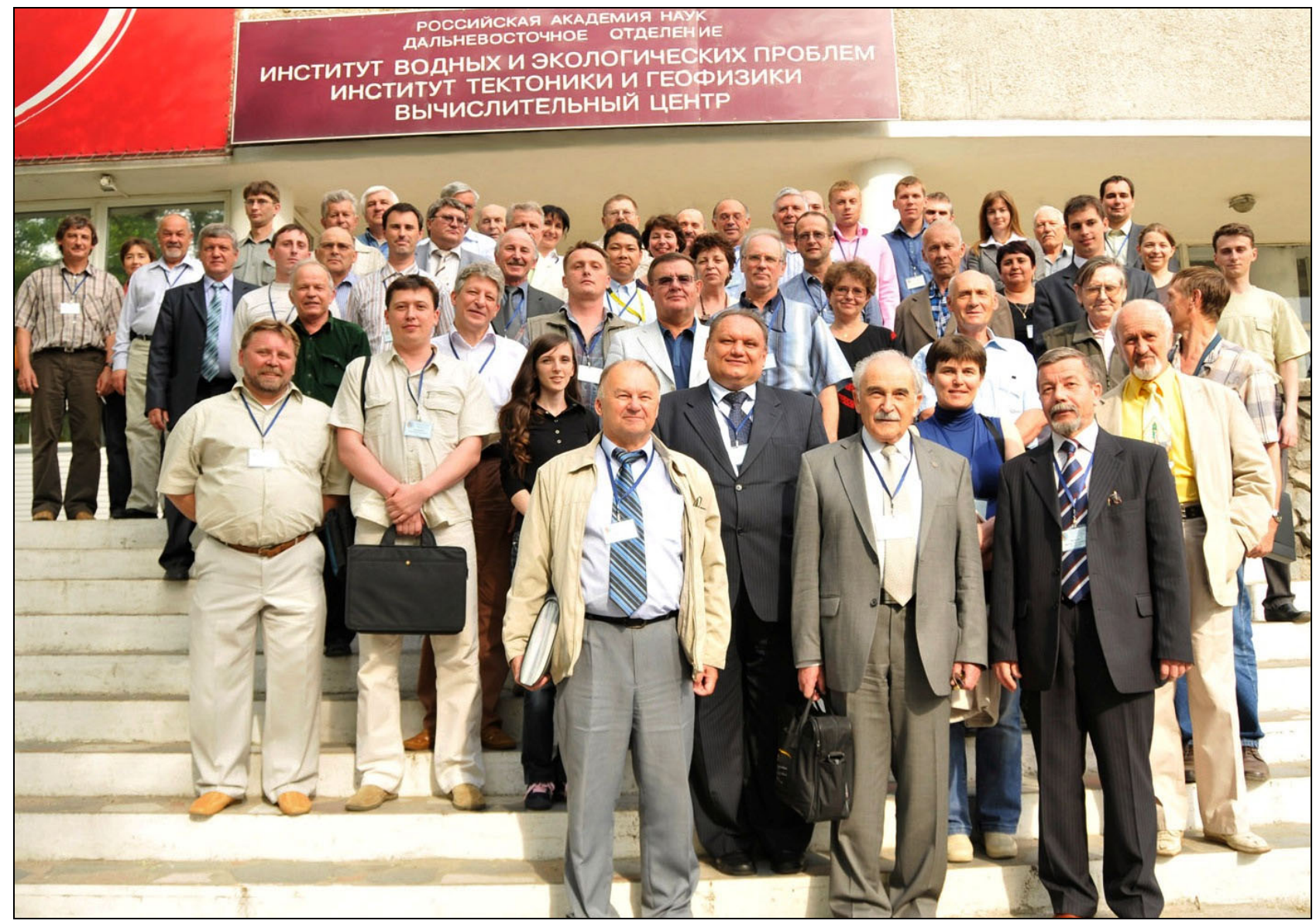

Участники симпозиума.

Participants of a symposium. 
Геодинамический режим территории Восточной Сибири и Дальнего Востока, ее высокая сейсмичность определяются, в первую очередь, взаимодействием континентальных Евразийской, Североамериканской, Амурской, с одной стороны, и океанических Тихоокеанской, Охотской плит - с другой. Существенное влияние на палео- и современную геодинамику региона оказывали и оказывают рифтогенные системы: Байкальская, Сунляо-Амуро-Зейская, Амуро-Ханкайская, Япономорская и Охотская.

Наложение этих двух геодинамических режимов и определяет главным образом напряженно-деформированное состояние литосферы региона, активность разломов и их плотность, сейсмичность, кинематику горизонтальных и вертикальных перемещений литосферных плит и крупных блоков. Согласно современным геолого-геофизическим данным, границы крупных литосферных плит представляют собой сложным образом устроенные зоны, разделяющие эти плиты и состоящие из блоков, ограниченных сейсмоактивными разломами. В пределах этих зон передаются возникающие при взаимодействии плит тектонические напряжения. Выяснение механизмов накопления, распространения и перераспределения энергии медленных деформационных процессов, передачи и сброса тектонических напряжений на границах блоков и литосферных плит - одна из важнейших проблем геодинамики.

Показателем активности разломов, кроме тектонических признаков, являются и геодезические данные о современных подвижках вдоль разломов. Следствием относительно быстрых перемещений бортов активных разломов является сейсмичность.

Результаты совместного анализа сейсмичности, активных разломов и векторов горизонтальных перемещений (по данным GPS-измерений) служат главным критерием оценки современного состояния геодинамики литосферы и основой социально ориентированных исследований по прогнозу природных, в том числе катастрофических, опасностей.

Применение современных технических средств наблюдений (космическая геодезия, широкополосная сейсмология, радиолокационная съемка рельефа) и методик обработки данных открывает новые возможности для разработки целостной концепции современной геодинамической активности Дальнего Востока и Восточной Сибири.

Наиболее актуальным проблемам геологии и геофизики - современной геодинамике, сейсмичности, сейсмическому районированию и оценке сейсмической опасности территорий, сейсмотектонике, физике очага землетрясений - был посвящен симпозиум «Проблемы сейсмичности и современной геодинамики Дальнего Востока и Восточной Сибири», проведенный в Институте тектоники и геофизики им. Ю.А. Косыгина ДВО РАН 1-4 июня 2010 г. в г. Хабаровске. Симпозиум является седьмым в се- рии уже традиционных региональных сейсмологических совещаний (г. Хабаровск, 1997, 2001; г. Петропавловск-Камчатский, 1999, 2004; г. Южно-Сахалинск, 2002, 2007).

Особое внимание, как и прежде, уделялось сейсмичности - самому яркому проявлению современной геодинамики. Дальневосточный регион России находится в наиболее сейсмоактивной области Земли, где за последнее десятилетие произошел ряд крупных сейсмических событий. Проблема сейсмичности и современной геодинамики Дальнего Востока не только актуальна для фундаментальной науки, но важна для жизнедеятельности региона.

Основная тематика симпозиума непосредственно связана с динамикой деформационного и сейсмического процессов, мониторингом геофизической среды, закономерностями деформирования земной коры и их сейсмическими проявлениями в различных регионах Дальнего Востока и Восточной Сибири, с изучением сейсмогенных и очаговых зон, использованием ГИС-технологий при прогнозировании опасных природных явлений.

В работе симпозиума приняли участие специалисты из г. Москвы (ИФЗ РАН, ГИН РАН, ИПНГ РАН, МИТП РАН, ИМАШ РАН), г. Санкт-Петербурга (ФТИ РАН), г. Обнинска (Геофизическая служба РАН), г. Красноярска (Экологический центр РОПР), г. Иркутска (ИЗК СО РАН), г. Новосибирска (ИНГиГ СО РАН), г. Якутска (ИГАБМ СО РАН), г. Благовещенска (ИГиП ДВО РАН), г. Биробиджана (ИКАРП), г. Хабаровска (ИТиГ ДВО РАН, ИГД ДВО РАН, ВЦ ДВО РАН), г. Владивостока (ДВГИ ДВО РАН, ИПМ ДВО РАН, ТОИ ДВО РАН, ТИГ ДВО РАН), г. ЮжНоСахалинска (ИМГиГ ДВО РАН, СФ ГС РАН), Г. Петропавловска-Камчатского (ИВиС ДВО РАН, КФ ГС РАН), г. Магадана (СВКНИИ ДВО РАН), г. Саппоро, Япония (Университет Хоккайдо).

На симпозиуме было заслушано 19 докладов на двух пленарных и 52 доклада на пяти секционных заседаниях: современная динамика литосферы и модели геоструктур на разных глубинных уровнях; деформационные процессы в земной коре и верхней мантии; сейсмичность территорий, сейсмическое районирование, количественные оценки сейсмической опасности; сейсмический процесс, физика очага, предвестники и прогноз землетрясений; сейсмотектоника, сейсмогенные и очаговые зоны. Проведены дискуссии на заседаниях трех «круглых» столов: 1) целевая комплексная программа научных исследований ДВО РАН «Современная геодинамика, активные геоструктуры и природные опасности Дальнего Востока России»; 2) деформационные волны Земли: приложение к сейсмичности и современной геодинамике; 3) уточнение сейсмичности и сейсмической опасности на территории Российской Федерации, создание карт общего сейсмического районирования следующего поколения - ОСР-2012. 
На пленарных заседаниях симпозиума были заслушаны доклады, затрагивающие практически все основные проблемы современной геодинамики и сейсмологии.

Высокий уровень симпозиума был задан первым пленарным докладом С.И. Шермана (ИЗК СО РАН, г. Иркутск) «Тектонофизическая модель континентальной сейсмической зоны: опыт разработки и проблемные задачи». На основе хорошо изученной разломной тектоники и сейсмичности Байкальской рифтовой зоны предложена тектонофизическая модель этой зоны, которая имеет высокую научную и практическую значимость, так как благодаря использованию современных ГИС-технологий позволяет рассчитывать вероятность появления отдельных очагов, что приближает нас к средне- и краткосрочному прогнозу землетрясений.

Исследование деформационных волн в разломных зонах, которые могут инициировать землетрясения, является актуальной проблемой. Этой теме было посвящено два пленарных доклада Ю.О. Кузьмина (ИФЗ РАН, г. Москва) и В.Г. Быкова (ИТиГ ДВО РАН, г. Хабаровск). В первом докладе эмпирически исследована пространственно-временная миграция современных деформаций в разломных зонах, которая трактуется в рамках существующих представлений об автоволновых процесcax; во втором - предложена модель накопления и распространения энергии медленных деформационных процессов, передачи и сброса напряжений на границах литосферных плит в зонах трансформных разломов.

В докладе Г.И. Долгих (ТОИ ДВО РАН, г. Владивосток) был проведен анализ технических характеристик аппаратно-программных комплексов, созданных на основе различных широкополосных сейсмографров, GPS-приёмников, деформографов, гидрофонов с позиций их применения при изучении вариаций напряжённо-деформационного поля Земли, вызывающих природные катастрофы. Особое внимание было уделено возможности создания аппаратуры на основе современных лазерно-интерференционных методов при проведении прямых высокоточных измерений разных параметров атмосферы, гидросферы и литосфреры в различных временных и пространственных масштабах.

В докладе Х. Такахаши (Университет Хоккайдо, г. Саппоро, Япония) были представлены геодезические и сейсмологические доказательства того, что сильные землетрясения вдоль Японии и на о. Сахалин связаны с накоплением и разрядкой напряжений на границе Амурской и Тихоокеанской плит и смещением первой плиты в направлении Японии.

Методика и принципы построения карт общего сейсмического районирования территории Российской Федерации ОСР-2012 были изложены в докладе В.И. Уломова (ИФЗ РАН, г. Москва) и С.А. Перетокина (Экологический центр РОПР, г. Красноярск).

Изучению линейных структур, которые занимают особое место в решении проблем современной геодинамики и сейсмологии, был посвящен доклад А.Н. Диденко с соавторами (ИТиГ ДВО РАН, г. Хабаровск). В работе на основе ГИС-технологий про- веден комплексный анализ потенциальных геофизических полей, цифровой модели рельефа и сейсмичности зоны сочленения Центрально-Азиатского складчатого пояса и Сибирского кратона.

Закономерности структурообразования и кинематические типы сопряжения активных разломов в зонах динамического влияния региональных тектонических швов, которые образуют разломно-блоковые структуры северо-восточного фланга Байкальского рифта и являются концентраторами значительных тектонических напряжений, рассматривались в докладе В.С. Имаева с соавторами (ИЗК СО РАН, г. Иркутск).

В докладе Н.И. Селиверстова (ИВиС ДВО РАН, г. Петропавловск-Камчатский) в рамках гидроконвекционной модели островодужного магматизма (на примере Ключевского вулкана) представлена возможная природа сейсмоактивных зон под действующими вулканами. Из доклада следует, что значительная часть проявлений сейсмичности действующих вулканов в виде глубоких длиннопериодных землетрясений и вулканического тремора может быть связана с процессами дегидратации магмы в магматических каналах и замкнутой магматической циркуляцией под вулканами островных дуг.

На втором пленарном заседании, в заключительный день симпозиума, прозвучали доклады А.В. Ландера с соавторами (МИТП РАН, г. Москва, КФ ГС РАН, г. Петропавловск-Камчатский) о сейсмических зонах Камчатки, И.Н. Тихонова (ИМГиГ ДВО РАН, г. Южно-Сахалинск) об исследовании пауз молчания как среднесрочных предвестниках сильных землетрясений Курило-Камчатской зоны, В.Н. Чеброва с соавторами (КФ ГС РАН, г. Петропавловск-Камчатский) об информационном обеспечении службы предупреждения о цунами на Дальнем Востоке.

В докладе Б.В. Левина (ИМГиГ ДВО РАН, г. Южно-Сахалинск) «Сейсмотектоника и земные приливы» были представлены предварительные результаты исследования зависимости сейсмоактивности элементов литосферы Тихоокеанского региона от их широтного положения. Предложена методика исследования сейсмической активности, включающая нормировку количества событий на длину границ литосферных плит в каждом широтном поясе, и проведен анализ распределения энергии землетрясений в широтных поясах по глубинам.

В докладе А.И. Кожурина с соавторами (ГИН РАН, г. Москва) был приведен анализ палеосейсмодислокаций в зонах разломов о. Сахалин, который кроме оценки магнитуд землетрясений позволяет оценить повторяемость землетрясений, что представляет интерес для долгосрочного прогноза.

На заседании секции «Современная динамика литосферы и модели геоструктур на разных глубинных уровнях» было заслушано девять докладов. Большое внимание в докладах В.Ю. Тимофеева с соавторами (ИНГиГ СО РАН, г. Новосибирск), С.В. Ашуркова (ИЗК СО РАН, г. Иркутск) с соавторами было уделено кинематике и определению границ Амурской плиты. По результатам измерений, представленным в первом докладе, определено по- 
ложение полюса вращения плиты относительно Евразии. Второй доклад был посвящен уточнению положения северной и восточной границ Амурской плиты.

В двух докладах Т.К. Злобина и А.Ю. Полец (ИМГиГ ДВО РАН, г. Южно-Сахалинск) приведен анализ динамики литосферы и ее дислокаций на разных глубинных уровнях Курило-Охотского и Сахалинского регионов. Представленные результаты имеют большое значение для определения реологических свойств земной коры и мантии этих регионов.

На секции «Сейсмичность территорий, сейсмическое районирование, количественные оценки сейсмической опасности» прозвучали доклады, в большей части которых дана оценка сейсмичности территорий Дальнего Востока. В докладе Т.В. Нагорных и Н.С. Коваленко (ИМГиГ ДВО РАН, СФ ГС РАН, г. Южно-Сахалинск) был представлен каталог землетрясений Приморья и Приамурья с 1865 по 2009 г. Авторы доклада пришли к выводу, что на территории Приморского края землетрясения с M=4.4 могут вызывать в эпицентре сотрясения до 7 баллов. Уточнение сейсмической опасности юга Приморья в настоящее время приобретает особую значимость в связи с интенсивным строительством на о. Русском и на территории Южного Приморья. Аналогичные исследования выполнены М.Ю. Андреевой (ИМГиГ ДВО РАН, г. Южно-Сахалинск) для Курило-Камчатской сейсмоактивной зоны.

Новые разработки по методике оценки уровня сейсмичности и сейсмической опасности нашли отражение в докладах В.А. Салтыкова (КФ ГС РАН, г. Петропавловск-Камчатский) и М.Ю. Андреевой (ИМГиГ ДВО РАН, г. Южно-Сахалинск).

Большой интерес вызвал доклад О.В. Луниной и А.С. Гладкова (ИЗК СО РАН, г. Иркутск), в котором была представлена новая систематика активных разломов, позволяющая в будущем перейти на новый уровень оценки сейсмической опасности.

Землетрясения на о. Сахалин (г. Нефтегорск, 27.05.1995 г.; г. Невельск, 02.08.2007 г.), повлекшие за собой сильные разрушения и человеческие жертвы, обусловили необходимость проведения детального районирования населенных пунктов о. Сахалин. Результаты этих исследований отражены в докладах Ким Чун Уна с соавторами (ИМГиГ ДВО PAН, г. Южно-Сахалинск, ИО РАН, г. Москва), А.В. Коновалова с соавторами (ИМГиГ ДВО РАН, г. Южно-Сахалинск).

Заседание секции «Дефрормационные процессы в земной коре и верхней мантии» было посвящено различным проявлениям волновых деформационных процессов, оказывающих значимое влияние на геодинамику сейсмических районов, особенно граничащих с активными сегментами Тихоокеанского сейсмического пояса. В докладе В.А. Бормотова (ИТиГ ДВО РАН, г. Хабаровск) приведены результаты исследования деформационных волновых процессов на территории Приамурья, позволяющие прогнозировать периоды активизации сейсмичности.

Анализ медленных деформационных волновых процессов в литосфере Байкальской рифтовой зоны представлен в докладе С.И. Шермана и Е.А. Горбуновой (ИЗК СО РАН, г. Иркутск). Убедительно показано, что одним из триггерных источников фиксируемой тенденции разрастания разрывов и временной последовательности формирования в них очагов землетрясений могут быть деформационные волны.

Деформационные волны на востоке Азии могут порождать не только слабые, но и сильные землетрясения. Доклад А.А. Степашко (ИТиГ ДВО РАН, г. Хабаровск) посвящен природе сейсмических циклов, в течение которых наблюдаются сильные землетрясения.

Прикладное значение исследования геодинамических процессов при решении сложных научнотехнических задач в ходе сооружения трубопроводной системы для транспорта нефти и газа от Пильтун-Астохского и Лунского месторождений до завода сжижения природного газа вблизи г. Южно-Сахалинска и добывающих платформ, расположенных на морском шельфе восточного побережья о. Сахалин, было отражено в докладе А.И. Никонова с соавторами (ИФЗ РАН, ИПНГ РАН, г. Москва).

Основная часть докладов секции «Сейсмический процесс, фризика очага, предвестники и прогноз землетрясений» посвящена главной проблеме сейсмологии - прогнозу усиления сейсмической активности. Возникновение аномалий сейсмической эмиссии, которые, по мнению авторов, обусловлены развитием приповерхностных зон дилатансии перед камчатскими землетрясениями, было проанализировано в докладе В.А. Салтыкова и Ю.А. Кугаенко (КФ ГС РАН, г. Петропавловск-Камчатский). Механизм предвестника гидрогеодинамического типа перед Кроноцким землетрясением (5.12.1997г.) рассматривался в докладе Г.Н. Копыловой и С.В. Болдиной (КФ ГС РАН, г. Петропавловск-Камчатский).

Большой интерес вызвали доклады М.Н. Луневой (ИТиГ ДВО РАН, г. Хабаровск) о новых данных по изучению сейсмической анизотропии в ЮжноКурильской дуге, А.В. Викулина с соавторами (ИВиС ДВО РАН, г. Петропавловск-Камчатский) о связи сейсмического и вулканического процессов на окраине Тихого океана.

В исследовании сейсмической активности важную роль играет развитие сети сейсмических станций, систем сбора информации и совершенствование методики определения характеристик землетрясений. Перспективам развития сети региональных сейсмических станций на юге Дальнего Востока был посвящен доклад Ю.Н. Левина с соавторами (СФ ГС РАН, г. Южно-Сахалинск). Вопросы создания системы сбора, хранения и передачи сейсмологической информации для сети ДВО рассмотрены В докладе А.А. Сорокина (ВЦ ДВО РАН, г. Хабаровск) и А.В. Коновалова (ИМГиГ ДВО РАН, г. ЮжноСахалинск).

На заседании секции «Сейсмотектоника, сейсмогенные и очаговые зоны» прозвучали доклады, в которых большое внимание уделено связи сейсмичности с современной тектоникой. Значимым ин- 
дикатором тектонической активности недр являются активные разломы и разломные зоны. Вопросам выделения разломов разными методами, оценки их активности посвящен ряд докладов: А.А. Гаврилова (ТОИ ДВО РАН, г. Владивосток), М.Н. Кондратьева (СВКНИИ ДВО РАН, г. Магадан), А.М. Жирнова (ИКАРП ДВО РАН, г. Биробиджан). Связь аномалий радона и гелия с активной разломной тектоникой и сейсмичностью отмечалась в докладах А.Т. Сорокиной с соавторами (ИГиП ДВО РАН, г. Благовещенск) и А.А. Коковкина (ИТиГ ДВО РАН, г. Хабаровск).

Изучению сейсмотектонических деформаций на Камчатке с применением георадара посвящен доклад Т.К. Пинегиной (ИВиС ДВО РАН, г. Петропавловск-Камчатский) и А.И. Кожурина (ГИН РАН, г. Москва).

Круг рассмотренных на симпозиуме вопросов отражает современное состояние и достижения мировой науки в прогнозе природных опасностей. Представленные результаты геодинамических, деформационных и сейсмологических исследований будут способствовать созданию информационной основы для оценки и уточнения сейсмической опасности на территории Дальнего Востока и Восточной Сибири.

Значительная часть докладов симпозиума является результатом исследований, выполненных в рамках целевой комплексной программы ДВО РАН «Современная геодинамика, активные геоструктуры и природные опасности Дальнего Востока России» (2009-2013 гг.).

Проведение симпозиума осуществлялось при финансовой поддержке Российского фонда фундаментальных исследований (грант 10-05-06023-Г), Президиума ДВО РАН (грант 10-ІІІ-Г-08-025).

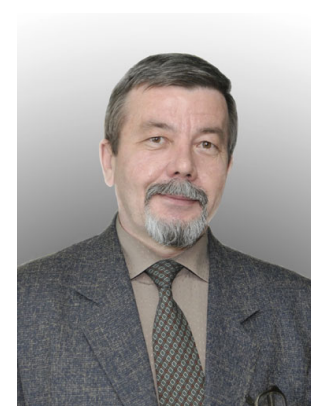

Быков Виктор Геннадьевич, докт. физ.-мат. наук, зам. директора института по научным вопросам Институт тектоники и геофизики им. Ю.А. Косыгина ДВО РАН 680000, Хабаровск, ул. Ким Ю Чена, 65, Россия Тел. 8(4212)227189; e-mail: bykov@itig.as.khb.ru

Bykov Victor G., Doctor of Physics and Mathematics, Deputy Director Yu.A. Kosygin Institute of Tectonics and Geophysics, Far Eastern Branch of RAS 680000, Khabarovsk, Kim Yu Chen street, 65, Russia Tel. 8(4212)227189; e-mail: bykov@itig.as.khb.ru

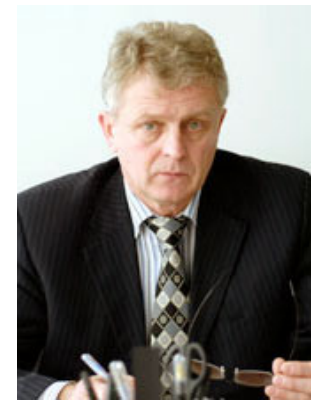

Диденко Алексей Николаевич, докт. геол.-мин. наук, директор института Институт тектоники и геофизики им. Ю.А. Косыгина ДВО РАН 680000, Хабаровск, ул. Ким Ю Чена, 65, Россия Тел. 8(4212)227499; e-mail: alexei_didenko@mail.ru

Didenko Alexei N, Doctor of Geology and Mineralogy, Director Yu.A. Kosygin Institute of Tectonics and Geophysics, Far Eastern Branch of RAS 680000, Khabarovsk, Kim Yu Chen street, 65, Russia Tel. 8(4212)227499; e-mail: alexei_didenko@mail.ru

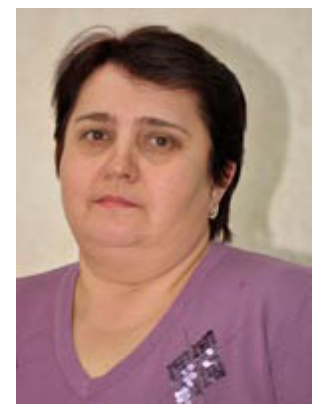

Меркулова Татьяна Владимировна, канд. геол.-мин. наук, н.с. Институт тектоники и геофизики им. Ю.А. Косыгина ДВО РАН 680000, Хабаровск, ул. Ким Ю Чена, 65, Россия

Тел. 8(4212)227189; e-mail: merkulova@itig.as.khb.ru

Merkulova Tat'yana V., Candidate of Geology and Mineralogy, Researcher Yu.A. Kosygin Institute of Tectonics and Geophysics, Far Eastern Branch of RAS 680000 , Khabarovsk, Kim Yu Chen street, 65, Russia Tel. 8(4212)227189; e-mail: merkulova@itig.as.khb.ru 